\title{
PENGARUH ALELOPATI SERESAH DAUN BAMBU (Dendrocalamus asper) PADA PERKECAMBAHAN KEDELAI (Glycine max L. Merril)
}

\author{
Lutfy Ditya Cahyanti ${ }^{1)}$ \\ 1)Progam Studi Agroteknologi Universitas Darussalam Gontor \\ 1)email: lutfyditya@unida.gontor.ac.id
}

Diterima 30 April 2019 disetujui 3 Mei 2019

\begin{abstract}
Weeds are an important factor in the decline of soybean production. One of weed control techniques that can be done is to use alelopati as an bioherbicide. One source of allelopathy that can be utilized as bioherbicide is bamboo leaf litter. Problems arise if this alelopati also affect the pattern of germination cultivation plants because one of the main requirements of bioherbisida is not to affect the growth and development of crops. The purpose of this study was to determine whether leaf litter alelopathy would affect the germination of soybeans. The hypothesis this research is that bamboo leaf litter alelopathy will not affect the germination of soybean crops so it will be safe to use as a pre-plant bioherbicide. The treated treatment is without litter solution of bamboo leaf, and dosage of $5 \%, 10 \%$, and $15 \%$ bamboo leaf litter solution. The design used was a complete non factorial randomized design with $5 x$ replication. The conclusion of this research is the treatment of allelopathy given by application of bamboo leaf litter with various doses has no significant effect on the germination, sprout length, and germination time of soybean crop, so that bamboo leaf litter solution is safe to be used as bioherbicide on sustainable agriculture.
\end{abstract}

Keywords: Soy bean, bamboo leaf litter, allelophaty, bioherbicide

\section{PENDAHULUAN}

Kedelai ialah salah satu komoditi pangan utama di Indonesia setelah padi dan jagung. Kedelai juga menjadi bahan pangan utama sumber protein nabati bagi masyarakat. Kebutuhan kedelai dari tahun ke tahun akan terus meningkat karena kedelai banyak dijadikan sebagai bahan baku makanan seperti tempe, tahu, tauco, maupun susu kedelai, sehingga kebutuhan kedelai dari tahun ke tahun akan terus meningkat. Akan tetapi untuk saat ini pasokan kedelai dalam negeri belum mampu mencukupi kebutuhan masyarakat.

Data Badan Pusat Statistik menunjukkan bahwa produksi kedelai di Indonesia pada tahun 2013 mencapai 779.992 ton, dengan konsumsi perkapita rata-rata 9,42 kg/tahun. Produktifitas rata-rata kedelai nasional juga rendah, tahun 2013 mencapai 14,16 ku/ha atau 1,4 ton/ha sedangkan potensi hasil di tingkat penelitian dan percobaan mencapai 2 ton (Badan Pusat Statistik, $2015^{\mathrm{a}}$ ) Untuk memenuhi kebutuhan kedelai dalam negeri, kekurangan kedelai tersebut harus dipenuhi dengan impor. Untuk mengurangi tingginya angka impor kedelai, perlu dilakukan berbagai usaha untuk meningkatkan produksi kedelai dalam negeri. Sedangkan untuk Kabupaten Ponorogo, berdasarkan data BPS tahun 2013, produksi kedelai mencapai 160.233 kuintal dengan produktivitas 16,78 kuintal/ha (Badan Pusat Statisti, 2015).

Faktor yang menyebabkan rendahnya produksi kedelai antara lain (a) Rendahnya kualitas benih dan varietas unggul yang dianjurkan tidak tersedia; (b) Olah tanah yang tidak tepat; (c) Persaingan dengan gulma ; (d) Cekaman kekeringan; (e) Serangan hama dan penyakit; (f) Keterbatasan tenaga kerja. Gulma akan bersaing dengan tanaman 
budidaya termasuk tanaman kedelai, yang meliputi persaingan ruang tumbuh dan adanya gulma akan menghambat penyerapan unsur hara tanaman budidaya sehingga akan menghambat laju pertumbuhan tanaman budidaya (Moenandir, 2010). Gulma dapat dikendalikan salah satunya dengan menggunakan bahan kimia sintetis. Salah satu dampak negatif dari penggunaan herbisida kimia sintetik adalah sisa residu yang akan menyebabkan kerusakan lingkungan dan berdampak pada kesehatan manusia sebagai konsumen hasil pertanian. Saat ini kesadaran masyarakat terhadap dampak penggunaan herbisida kimia sintetis pada kesehatan lingkungan telah menjadikan bioherbisida sebagai metode alternatif pengendalian gulma. Bioherbisida akan memberikan dampak tidak secara langsung pada tanaman budidaya sehingga tidak akan menyebabkan degradasi lingkungan dan tidak menimbulkan dampak pada kesehatan manusia (Riskitavani dan Purwani, 2013).

Salah satu sumber bahan baku bioherbisida adalah dengan dengan alelopati yang menggunakan senyawa golongan fenol dari berbagai macam tumbuhan sebagai alternatif bioherbisida. Prawinata, et al (1981) mengemukakan bahwa senyawa terpenoid, flavonoid dan fenol adalah alelokimia yang bersifat menghambat pembelahan sel sehingga dapat dipergunakan sebagai bioherbisida. Hasil fitokimia dari daun bambu diketahui mengandung flavonoid, kumarin dan fenolik. Selain itu, daun bambu mengandung senyawa kumarin, flavonoid dan fenolik, daun bambu juga mengandung antrakunion, polisakarida, dan asam amino (Yanda et al, 2013). Dari hasil penelitian kandungan fitokimia dan melimpahnya seresah daun bambu yang ada di sekitar lahan pertanian memungkinkan bagi seresah daun bambu untuk dijadikan sebagai bioherbisida solusi penghambat pertumbuhan gulma yang ramah lingkungan dan mendukung pertanian yang berkelanjutan. Permasalahan timbul apabila alelopati ini juga mempengaruhi pola perkecambahan tanaman budidaya karena salah satu syarat utama dari bioherbisida adalah tidak mempengaruhi pertumbuhan dan perkembangan tanaman budidaya.

Tujuan penelitian ini untuk mengetahui apakah alelopati seresah daun akan mempengaruhi perkecambahan kedelai. Hipotesis yang diajukan adalah bahwa alelopati seresah daun bambu tidak akan mempengaruhi perkecambahan tanaman kedelai sehingga akan aman digunakan sebagai bioherbisida pra tanam.

\section{METODE}

Perlakuan yang diberikan pada penelitian ini adalah tanpa larutan seresah daun bambu, serta dosis larutan seresah daun bambu 5\%, 10\%, dan $15 \%$. Rancangan yang digunakan adalah rancangan acak lengkap non factorial dengan 5 kali ulangan.

Pembuatan ekstrak alelopati dimulai dengan seresah daun bambu yang telah disiapkan ditimbang sebanyak 25 gram (untuk larutan 5\%), 50 gram (untuk larutan 10\%) dan 75 gram (untuk larutan $15 \%$ ) kemudian masing-masing diblender bersama $500 \mathrm{ml}$ aquades. Setelah merata dan terlihat telah lembut, cairan dimasukkan ke dalam labu ukur dan diberi label sesuai masing-masing perlakuan.

Parameter yang diamati meliputi panjang kecambah $(\mathrm{cm})$, daya tumbuh (\%) yang dihitung berdasarkan banyaknya biji yang mampu tumbuh dibandingkan dengan yang mati. Setelah 10 hst dilakukan pengamatan diperbandingkan dengan kontrol. Parameter berikutnya yang diamati adalah waktu saat berkecambah. Saat 
berkecambah dapat diukur dengan menghitung jumlah hari yang diperlukan untuk berkecambah.

\section{HASIL DAN PEMBAHASAN}

Hasil analisis ragam menunjukkan bahwa perlakuan pemberian seresah daun bambu dengan konsentrasi yang berbeda, tidak berpengaruh nyata pada daya tumbuh kecambah dan saat berkecambah biji kedelai. Data daya tumbuh dan saat berkecambah biji kedelai biji disajikan pada Tabel 1.

Tabel 1. Panjang Kecambah, Daya Tumbuh dan Saat Berkecambah Biji Kedelai Akibat Pengaruh Alelopati Larutan Seresah Daun Bambu

\begin{tabular}{cccc}
\hline Perlakuan & $\begin{array}{r}\text { Panjang Kecambah } \\
(\mathrm{cm})\end{array}$ & Daya tumbuh $(\%)$ & $\begin{array}{c}\text { Saat Berkecambah } \\
(\text { hari })\end{array}$ \\
\hline Kontrol & 10,7 tn & $83,3 \mathrm{tn}$ & $3,90 \mathrm{tn}$ \\
$5 \%$ & $8,7 \mathrm{tn}$ & $82,7 \mathrm{tn}$ & $3,95 \mathrm{tn}$ \\
$10 \%$ & $8,5 \mathrm{tn}$ & $81,0 \mathrm{tn}$ & $3,97 \mathrm{tn}$ \\
$15 \%$ & $7,3 \mathrm{tn}$ & $81,3 \mathrm{tn}$ & $3,99 \mathrm{tn}$
\end{tabular}

Keterangan:

Bilangan yang didampingi huruf yang sama pada kolom yang sama menunjukkan tidak berbeda nyata berdasarkan uji Duncan 5\%; hst= hari setelah tanam; tn= tidak nyata

Data hasil pengamatan menunjukkan bahwa perkecambahan kedelai secara umum tidak terpengaruh oleh pemberian larutan daun pinus. Pemberian larutan ekstrak daun pinus juga menunjukkan tidak ada perbedaan yang signifikan terhadap jumlah biji yang berkecambah. Tidak adanya pengaruh penghambatan karena faktor pertahanan biji secara morfologi maupun fisiologi terhadap tekanan lingkungan.

Tahap-tahap perkecambahan meliputi imbibisi air, hidrasi organ subseluler, perubahan organisasi subseluler, embrio dan kotiledon, perubahan aktivitas fitokrom, pengaktifan enzim, sintesa enzim, penguraian cadangan makanan, pengangkutan molekul organik ke arah embrio, sintesa protein dan penyusun sel, aktivitas respirasi, pembelahan sel, pemanjangan sel, sintesa atau pengaktifan bahan pertumbuhan, diferensiasi sel, pembagian bahan metabolik baru oleh embrio, dan perubahan derajat kebutuhan oksigen dan karbondioksida (Noggle dan Fritz,1983).

Perkecambahan biji dipengaruhi oleh beberapa faktor eksternal seperti air, suhu, komposisi udara, cahaya dan juga zat-zat toksis yang ada di lingkungannya, termasuk pula di dalamnya zat-zat alelopati dari tumbuhan atau sisa tumbuhan di sekitarnya. Adaptasi morfologi didasarkan pada penghambatan atau pencegahan masuknya senyawa berbahaya ke dalam tubuh tumbuhan misalnya adanya lignin. Adanya lignin pada dinding biji mencegah masuknya senyawa alelopati pada membran, sehingga sistem membran tidak mengalami kerusakan. Sifat permeabilitas benih juga ditentukan oleh faktor umur. Semakin tua benih, maka kadar lignin meningkat sehingga semakin rendah pula imbibisinya.

Struktur biji kacang-kacangan terluar terdiri atas kulit, hilum, mikrofil, dan khalaza. Kulit biji (testa) merupakan karakter morfologi penting biji karena menentukan proses fisiologis embrio, 
sekaligus menjadi penutup dan pelindung embrio. Kulit biji berperan dalam menentukan derajat dan kecepatan imbibisi air. Jumlah air yang diserap benih menentukan kecepatan berkecambah benih sehingga juga akan mempengaruhi kadar alelopat yang diserap oleh biji. Penggunaan alelopati daun pinus ini sangtt berpotensi digunakan sebagai bioherbisida, hal ini dikarenakan alelopati daun pinus dapat menekan pertumbuhan gulma dan tidak mempengaruhi tanaman budidaya.

\section{SIMPULAN}

Kesimpulan dari penelitian ini adalah perlakuan alelopati yang diberikan melalui aplikasi seresah daun bambu dengan berbagai dosis tidak berpengaruh nyata pada daya kecambah, panjang kecambah, dan waktu berkecambah tanaman kedelai, sehingga larutan seresah daun bambu aman dipergunakan sebagai bioherbisida ramah lingkungan.

\section{DAFTAR PUSTAKA}

Badan Pusat Statistik.2015. Pertanian dan pertambangan. http://bps.go.id/

Badan Pusat Statistik. 2015. Kabupaten
Ponorogo Dalam Angka. http://ponorogokab.bps.go.id/w ebsite3502/frontend/

Moenandir, J., 2010. Ilmu Gulma. Universitas Brawijaya Press, Malang.

Noggle, G.R and Frits, G.J. 1983. Introduction Plant Physiology, Second Edition. New Jersey: Prentice Hall, Inc, Englewood Clifts.

Riskitavani, Denada Visitia dan Kristanti Indah Purwani. 2013. Studi Potensi Bioherbisida Ekstrak Daun Ketapang (Terminalia catappa) terhadap Gulma Rumput Teki (Cyperus rotundus). Jurnal Sains dan Seni Pomits. 2 (2) : $59-63$.

Prawinata, W. 1981. Dasar-Dasar Fisiologi Tumbuhan Jilid I. ITB. Bandung.

Yanda, Muha Miko Imarta, Hazli Nurdin,dan Adlis Santoni. 2013. Isolasi Dan Karakterisasi Senyawa Fenolik Dan Uji Antioksidan Dari Ekstrak Daun Bambu (Dendrocalamus Asper). Jurnal Kimia Universitas Andalas2 (2) : 51-5 